\title{
Systemic ketamine inhibits hypersensitivity after surgery via descending inhibitory pathways in rats
}

\author{
[La kétamine intravasculaire inhibe l'hypersensibilité postchirurgicale par des \\ voies inhibitrices descendantes chez les rats]
}

Shiro Koizuka MD, Hideaki Obata MD, Masayuki Sasaki MD, Shigeru Saito MD, Fumio Goto MD

Purpose: Systemic ketamine suppresses several types of chronic pain. Although ketamine is used as a general anesthetic agent, the analgesic effect of systemic ketamine for early-stage postoperative pain is not clear. We investigated the efficacy and mechanism of systemic ketamine in a rat model of postoperative pain.

Methods: An incision was made in the plantar aspect of the left hind paw in male Wistar rats. Mechanical hypersensitivity was measured using calibrated von Frey filaments. The anti-hypersensitivity effect of systemic or intrathecal administration of ketamine was determined every hour after making the incision. We examined the effects of intrathecal pretreatment with yohimbine, an $\alpha_{2}$-adrenoceptor antagonist, and methysergide, a serotonergic receptor antagonist, on the anti-hypersensitivity effect of ketamine. We also examined the effect of systemic ketamine on the c-fos immunoreactivity in the spinal cord.

Results: Systemic administration of ketamine at doses from 3 to 30 $\mathrm{mg} \cdot \mathrm{kg}^{-1}$ produced anti-hypersensitivity effects in a dose-dependent manner. Intrathecal administration of ketamine had no effect. There was no significant difference between effects of pre- and post-incisional administration. Intrathecal pretreatment with yohimbine ( 10 $\mu \mathrm{g}$ ) or methysergide ( $5 \mu \mathrm{g}$ ) completely reversed the anti-hypersensitivity effects of systemic ketamine. Systemic ketamine reduced fos expression in laminae I-II in the dorsal horn of the lumbar spinal cord ipsilateral to the paw incision.

Conclusions: The results suggest that systemic administration of ketamine perioperatively suppresses early-stage postoperative pain via monoaminergic descending inhibitory pathways.
Objectif : La kétamine intravasculaire supprime certaines douleurs chroniques. Utilisée comme anesthésique général, son effet analgésique pour la douleur postopératoire de stade précoce n'est toutefois pas clair. Nous avons vérifié l'efficacité et le mécanisme de la kétamine intravasculaire chez un modèle rat de douleur postopératoire.

Méthode : Une incision a été faite dans la partie plantaire de la patte arrière gauche de rats mâles Wistar. L'hypersensibilité mécanique a été mesurée à l'aide de filaments von Frey calibrés. L'effet d'antihypersensibilité de la kétamine vasculaire ou intrathécale a été déterminé toutes les heures après l'incision. Nous avons étudié les effets du prétraitement intrathécal avec yohimbine, un antagoniste des récepteurs $\alpha_{2}$-adrénergiques, et méthysergide, un antagoniste des récepteurs sérotoninergiques, sur l'effet anti-hypersensibilité de la kétamine. Nous avons aussi vérifié l'effet de la kétamine intravasculaire sur l'immunoréactivité des c-fos dans la moelle épinière.

Résultats : L'administration intravasculaire de kétamine en doses de 3 à $30 \mathrm{mg} \cdot \mathrm{kg}^{-1}$ a produit des effets d'anti-hypersensibilité reliés à la dose. La kétamine intrathécale n'a pas eu d'effet. II n'y avait pas de différence significative entre les effets de l'administration pré-incisionnelle et post-incisionnelle. Le prétraitement intrathécal avec yohimbine ( $10 \mu \mathrm{g})$ ou méthysergide ( $15 \mu \mathrm{g})$ a complètement renversé les effets d'anti-hypersensibilité de la kétamine intravasculaire. La kétamine intravasculaire a réduit l'expression de fos dans la lame I-II de la corne supérieure de la moelle épinière lombaire homolatérale à l'incision de la patte.

Conclusion : Les résultats suggèrent que l'administration intravasculaire préopératoire de kétamine supprime la douleur postopératoire de stade précoce par des voies inhibitrices descendantes monoaminergiques.

From the Department of Anesthesiology, Gunma University Graduate School of Medicine, Maebashi, Japan.

Address correspondence to: Dr. Shiro Koizuka, Department of Anesthesiology, Gunma University Graduate School of Medicine, 3-39-

22, Showa-machi, Maebashi, Gunma, 371-8511, Japan. Phone: 81-272-20-8454; Fax: 81-272-20-8473; E-mail: skoizuka@aol.com This study was supported by a Grant-in Aid (No. 12671451) and Department Sources for Scientific Research from the Ministry of Education, Science, Sports and Culture of Japan. Accepted for publication November 15, 2004.

Revision accepted February 8, 2005. 


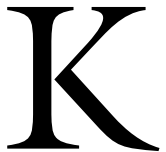

ETAMINE is a widely used general anesthetic with analgesic effects. Ketamine is also administered systemically and produces analgesia in several types of chronic pain, such as phantom limb pain, post-herpetic neuralgia, and orofacial pain. ${ }^{1-3}$ Surgery is another common cause of persistent pain and hyperalgesia. Brennan et al. ${ }^{4}$ developed a postoperative pain model in rats by making an incision in the paw. Hypersensitivity (reduction of withdrawal threshold from stimuli) around the incision site differs from hypersensitivity due to nerve injury or during inflammation, and is pharmacologically unique. ${ }^{4-6}$ Although systemic ketamine is effective for postoperative pain in humans, ${ }^{7,8}$ the effect of systemic ketamine in this model has not been examined. The first purpose of the current study is to evaluate the efficacy of systemic ketamine for postoperative pain in rats. Anti-hypersensitivity is defined as inhibition of reduction of withdrawal threshold after paw-incision.

Preemptive analgesia, pain relief strategies performed before tissue injury, can modify the development and maintenance of postoperative pain in patients. ${ }^{9,10}$ The efficacy of preemptive analgesia clinically ${ }^{11}$ and in postoperative pain models is controversial. ${ }^{5}$ The second purpose of the present study is to compare the effects of pre- and post-incisional ketamine administration in this model.

Although the antinociceptive effects of systemic ketamine are considered to be mediated by spinal cord and supraspinal sites, ${ }^{12}$ the precise mechanism is not fully understood. Activation of the N-methyl-D-aspartate (NMDA) receptors in the spinal cord is important for the induction and maintenance of sustained pain. ${ }^{13,14}$ Ketamine inhibits NMDA receptors in a noncompetitive manner, ${ }^{15}$ and intrathecal or systemic administration of ketamine reduces nerve injury-induced hyperalgesia or inflammatory pain in rats. ${ }^{13,14,16-18}$ Ketamine also has antinociceptive effects for acute pain induced by the tailflick test ${ }^{19,20}$ in which NMDA receptor antagonists are not effective. ${ }^{21}$ Several behavioural and electrophysiologic studies suggest that ketamine produces antinociceptive effects through activation of monoaminergic descending inhibitory pathways. ${ }^{19,20,22-24}$ The mechanism of the antinociceptive effects of ketamine is suggested to depend upon the presence peripheral inflammation. ${ }^{22}$ The third purpose of the current study is to clarify the mechanism of the antinociceptive effects of systemic ketamine. Site of action and involvement of noradrenergic and serotonergic systems were examined in the postoperative pain model.

Immunocytochemical localization of Fos, which is the protein product of the immediate-early pro- tooncogene c-fos, is widely used to identify populations of neurons in the spinal cord that are activated by peripheral noxious stimuli. ${ }^{25,26} \mathrm{We}$ examined the effect of systemically administered ketamine on Fos immunoreactivity induced by paw incision.

\section{Materials and methods}

This investigation was approved by the Animal Care and Use Committee of Gunma University Graduate School of Medicine (Maebashi, Japan). Male Wistar rats weighing 250 to $300 \mathrm{~g}$ were used in all experiments. All surgical procedures were performed under general anesthesia (isoflurane $2-3 \%$ in oxygen). At the end of the protocol, all animals were sacrificed with an overdose of pentobarbital.

\section{Foot incision}

The surgery was based upon the procedure described by Brennan et al. ${ }^{4}$ A longitudinal $1-\mathrm{cm}$ incision was made through the skin and fascia, starting at $0.5 \mathrm{~cm}$ from the edge of the heel and extending toward the toes of the left hind paw. The plantaris muscle was elevated using forceps and incised longitudinally. The wound was closed with two mattress sutures of 5-0 nylon. Gentamycin solution was applied to the wound site. After surgery, the rats recovered in their cages.

\section{Intrathecal catheter placement}

Intrathecal catheters were placed in some rats for intrathecal administration of drugs. After sterile preparation of the posterior neck, a polyethylene catheter (PE-10) was inserted through an opening in the atlanto-occipital membrane to the lumbar spinal cord $(8.0 \mathrm{~cm})$ according to the method described by Yaksh and Rudy. ${ }^{27}$ After recovery, the animal was examined for any apparent motor or sensory deficits; if any were present, the animal was excluded from the study. Experiments were performed for five to seven days after intrathecal catheter placement.

\section{Behavioural testing}

Rats were placed individually in a cage with a wire mesh bottom that allowed full access to the paws. Withdrawal thresholds to punctate mechanical stimulation were determined using the method described by Brennan et al. ${ }^{4}$ with calibrated von Frey filaments (Stoelting, Wood Dale, IL, USA). Each von Frey filament was applied vertically to an area adjacent to the wound for six seconds while the filament was gently bent, starting with $0.2 \mathrm{~g}$ and continuing until a withdrawal response occurred or $28.8 \mathrm{~g}$ (cut-off value) was reached. This procedure was repeated three times with a three- to five-minute test-free period between with- 
drawal responses. The lowest force obtained in the three tests producing a response was defined as the withdrawal threshold. The cut-off value, $28.8 \mathrm{~g}$, was recorded even if there was no withdrawal response to this force. The withdrawal threshold was measured before the incision was made (baseline threshold), and then at one-hour intervals for four or six hours thereafter. The general behaviour of the rats was carefully observed after drug injection. Motor function was evaluated by examining the righting reflex, stepping reflex, posture, and ambulation. Sedation was assessed in terms of spontaneous movement such as grooming and chewing, as well as evoked movement (a startle reflex evoked by tapping on the cage). The investigator responsible for the behavioural studies was blind to the drug treatment of each animal.

\section{Drugs and injections}

Ketamine hydrochloride, yohimbine hydrochloride, an $\alpha_{2}$-adrenoceptor antagonist, and methysergide hydrochloride, a non-selective serotonergic receptor antagonist, were purchased from Sigma Chemical Co. (St. Louis, MO, USA). Systemic drug administration was subcutaneously injected in a single injection volume of $0.5 \mathrm{~mL}$. Rats were injected systemically with ketamine either immediately after $(3,10$, and 30 $\left.\mathrm{mg} \cdot \mathrm{kg}^{-1}\right)$ or ten minutes before making the incision $\left(10\right.$ and $30 \mathrm{mg} \cdot \mathrm{kg}^{-1}$ ). In the preliminary experiment, $s c$ injection of ketamine produced the effect within ten minutes. Intrathecal drug administration was performed using a microinjection syringe (Hamilton, Reno, NV, USA) in a volume of $10 \mu \mathrm{L}$, followed by $10 \mu \mathrm{L}$ saline to flush the catheter. Rats were injected with ketamine $(10,30$, and $100 \mu \mathrm{g})$ intrathecally immediately after making the incision. To verify that the effect of systemic ketamine on post-incisional hypersensitivity was produced by descending monoaminergic inhibitory pathways, $10 \mu \mathrm{g}$ of yohimbine or $15 \mu \mathrm{g}$ of methysergide were administered intrathecally ten minutes before making the incision, followed by $s c$ administration of $30 \mathrm{mg} \cdot \mathrm{kg}^{-1}$ of ketamine immediately after making the incision. The doses of antagonists were selected according to a previous report. ${ }^{22}$ All drugs were dissolved in saline.

\section{c-fos protein-like immunoreactivity}

Rats received either $30 \mathrm{mg} \cdot \mathrm{kg}^{-1}$ of ketamine $(n=5)$ or saline $(n=6)$ subcutaneously immediately after paw incision, and the expression of Fos protein was examined two hours after making the incision. The rats were deeply anesthetized with pentobarbital sodium (100-150 $\mathrm{mg} \cdot \mathrm{kg}^{-1}$, intraperitoneally) and transcardially perfused with saline, followed by $4 \%$ paraformalde- hyde in $0.1 \mathrm{M}$ phosphate buffer $(\mathrm{pH}=7.4)$. The spinal cord was dissected out, postfixed in the same fixative overnight, and cryoprotected by immersion in $0.1 \mathrm{M}$ phosphate buffer containing $20 \%$ sucrose. Three days later, the spinal cord segments containing L4-L5 were frozen with powdered dry ice, and then cut transversely into $30 \mu \mathrm{m}$ sections using a cryostat. The sections were immunostained using the avidinbiotin complex with nickel ammonium sulfate intensification. The primary antibody for $c$-fos protein (Ab-5, Oncogene Research Products, MA, USA) was diluted 1:10000 with $0.1 \mathrm{M}$ phosphate buffer saline (PBS) containing 5\% normal rabbit serum. In this solution, the sections were incubated for $72 \mathrm{hr}$ at $4^{\circ} \mathrm{C}$. After rinsing with 0.1 M PBS, they were incubated in biotinylated rabbit anti-sheep IgG (Vector Laboratories, Burlingame, CA, USA) diluted 1:400 in PBS containing 5\% normal rabbit serum for $24 \mathrm{hr}$ at $4^{\circ} \mathrm{C}$. After rinsing with PBS, the sections were incubated in $30 \%$ methanol and $1 \% \mathrm{H}_{2} \mathrm{O}_{2}$ in $0.1 \mathrm{M}$ PBS for $15 \mathrm{~min}$ to inactivate endogenous peroxidase. The sections were incubated with avidin-biotin complex reagent (Vector Laboratories) in PBS for two hours at $4^{\circ} \mathrm{C}$. The sections were then reacted in $0.05 \%$ diaminobenzidine and $0.01 \% \mathrm{H}_{2} \mathrm{O}_{2}$ in $0.1 \mathrm{M}$ Tris-

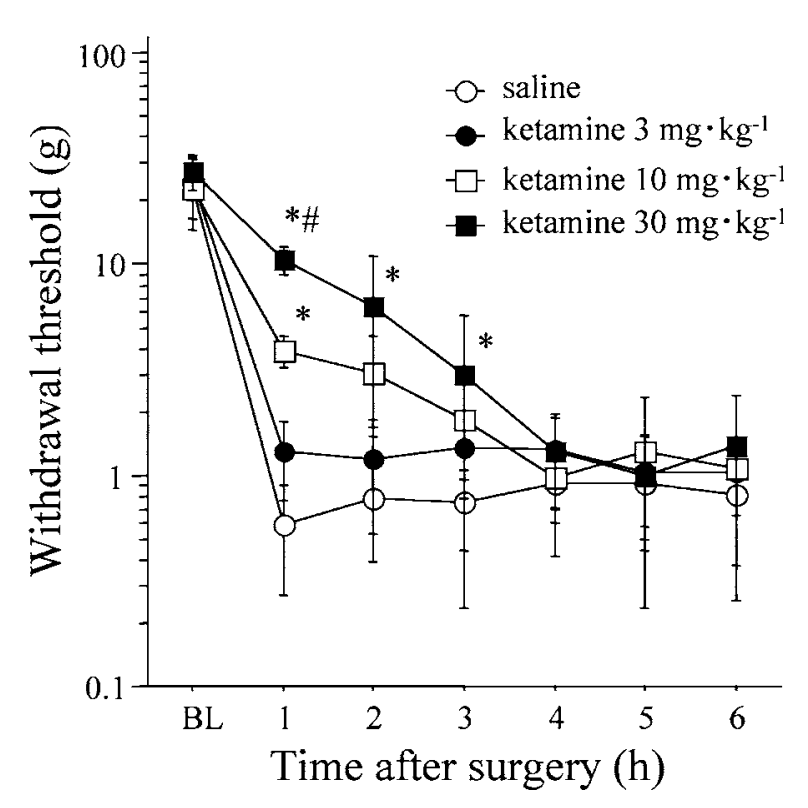

FIGURE 1 Dose-dependent reduction in punctate mechanical hypersensitivity produced by systemic ketamine administered subcutaneously immediately after incision. Each point represents the mean $\pm \mathrm{SD}$ ( $n=8$ in each group). The withdrawal thresholds are on a $\log$ scale. $\mathrm{BL}=$ baseline withdrawal threshold measured before paw incision surgery. ${ }^{*} P<0.05 v s$ saline-treated group. \#P $<0.05$ vs $10 \mathrm{mg} \cdot \mathrm{kg}^{-1}$ of ketamine-treated group. 
HCl-buffered saline $(\mathrm{pH}=7.4$ ) containing $0.2 \%$ nickel ammonium sulfate for five minutes. The tissue sections were mounted onto gelatin-coated slides, air dried, dehydrated in a graded series of ethanol, cleared in xylene, and coverslipped.

Five to ten sections of the spinal cord segments (L4-L5) were randomly selected from each rat. The dorsal horn of each section was divided into three regions (laminae I/II, III/IV, and V/VI) as described previously, ${ }^{28}$ and the number of $\mathrm{c}$-fos protein positive neurons in each area was counted. The average number of $\mathrm{c}$-fos protein-positive neurons in the five to ten sections was defined as the number of c-fos-positive neurons.

\section{Statistical analysis}

Data are presented as the mean \pm SD. The data of withdrawal threshold were analyzed with nonparametric statistics. The Kruskal-Wallis test and MannWhitney test were used. Multiple comparisons after the Kruskal-Wallis test were performed by using the Dunn test. One-way analysis of variance was used to assess differences in number of c-fos immunoreactive neurons, followed by post hoc testing using the Dunn test for multiple comparison. A $P$ value of less than 0.05 was considered statistically significant.

\section{Results}

Effects of ketamine on general behaviour and incisioninduced mechanical hypersensitivity

Paw incision reduced the paw withdrawal threshold one hour after surgery compared to pre-surgical values (22.9 g before, $0.6 \mathrm{~g}$ after, $P<0.05, n=8$, Figure 1 ). Systemic administration of ketamine produced antihypersensitivity effects in a dose-dependent manner $(P$ $<0.05$, Dunn test). The maximum dose of ketamine increased the withdrawal threshold for three hours after surgery compared to saline $(P<0.05$, Dunn test, Figure 1). There were no differences in the withdrawal thresholds between the group that received 10 or $30 \mathrm{mg} \cdot \mathrm{kg}^{-1}$ of systemic ketamine ten minutes before and the group that received the same doses of systemic ketamine immediately after the incision was made (Figure 2). The rats were not sedated and motor function assessed by the righting/stepping reflex, posture, and ambulation was normally preserved at $60 \mathrm{~min}$ after systemic administration of ketamine. Intrathecal administration of ketamine at doses from 10 to $100 \mu \mathrm{g}$ did not produce an anti-hypersensitivity effect (Figure $3)$. Systemic injection of 10 or $30 \mathrm{mg} \cdot \mathrm{kg}^{-1}$ of ketamine produced several characteristic behavioural effects, in addition to analgesia. After administration, the rats exhibited head weaving and circling behaviour that

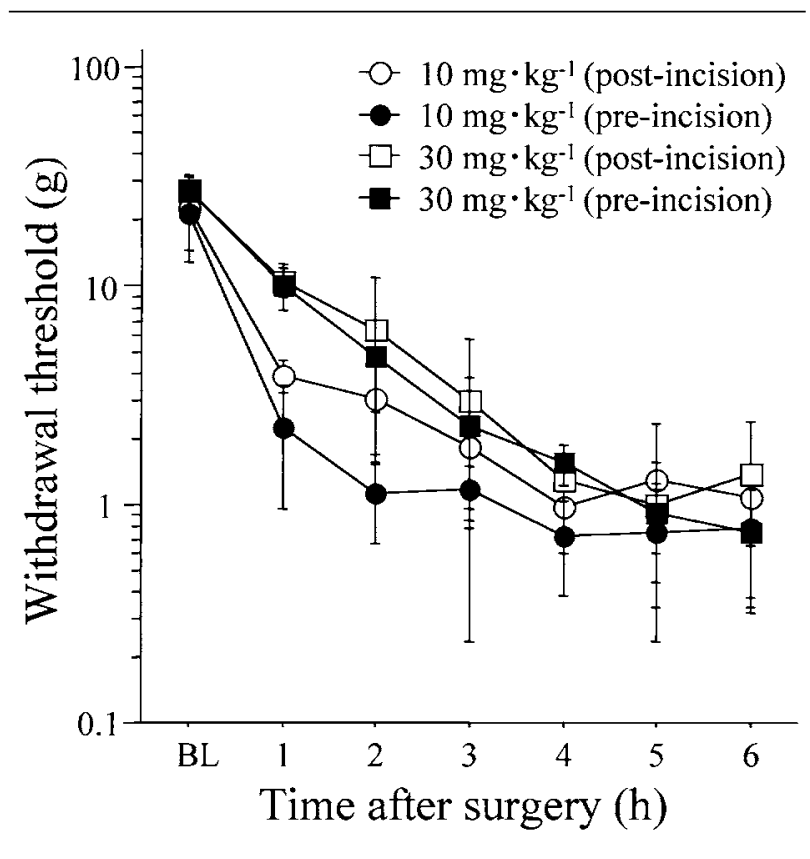

FIGURE 2 Comparison of pre- $v s$ post-incisional administration of systemic ketamine on the withdrawal threshold after paw surgery. Each point represents the mean $\pm \mathrm{SD}(n=8$ in each group). The withdrawal thresholds are on a $\log$ scale. $\mathrm{BL}=$ baseline withdrawal threshold measured before paw incision surgery.

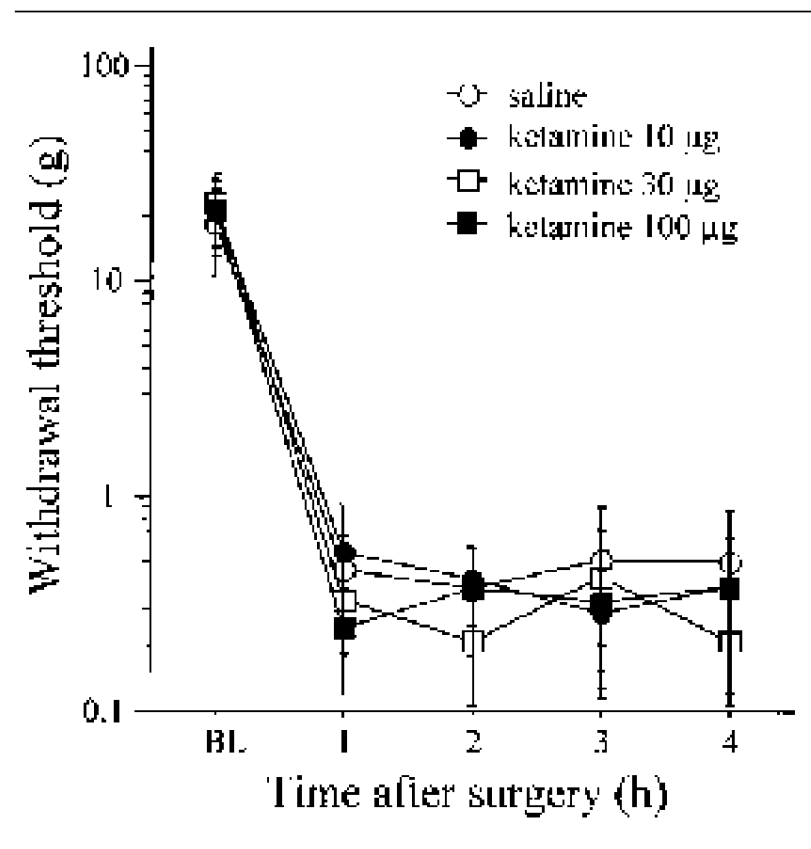

FIGURE 3 The effect of intrathecal administration of ketamine on withdrawal threshold after paw incision. Each point represents the mean $\pm \mathrm{SD}$ ( $n=6$ in each group). The withdrawal thresholds are on a $\log$ scale. $\mathrm{BL}=$ baseline withdrawal threshold measured before paw incision surgery. 


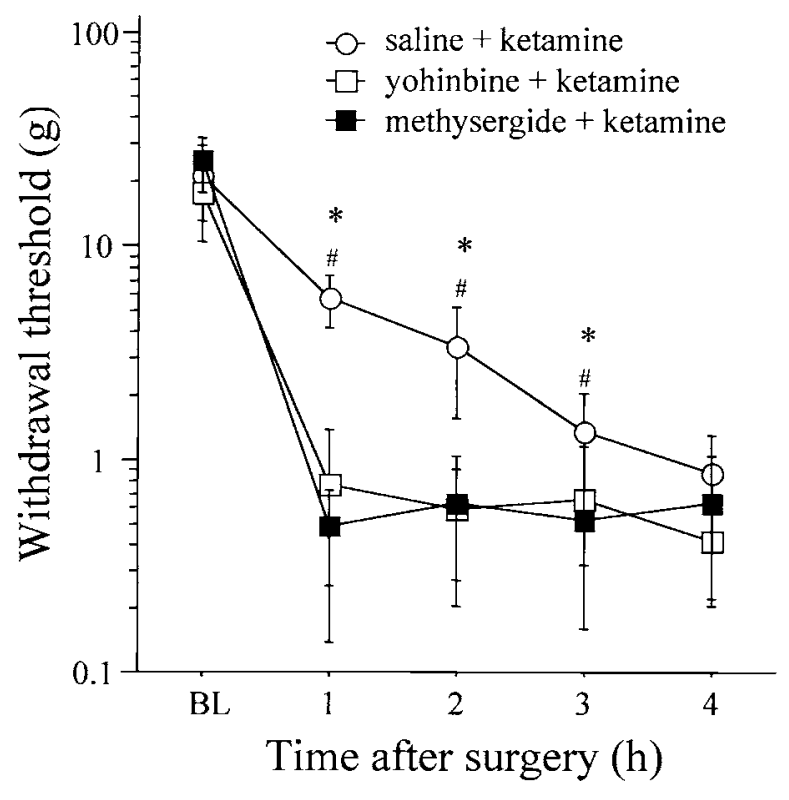

FIGURE 4 Effects of pretreatment with intrathecal administration of yohimbine or methysergide on antihypersensitivity effects of $30 \mathrm{mg} \cdot \mathrm{kg}^{-1}$ of systemic ketamine. Each point represents the mean \pm SD ( $n=6$ in each group). The withdrawal thresholds are on a $\log$ scale. $\mathrm{BL}=$ baseline withdrawal threshold measured before paw incision surgery. ${ }^{*} P<0.05$ vs yohimbine-pretreated group. $\# P<0.05$ vs methysergide-pretreated group.

persisted for 30 to $50 \mathrm{~min}$. Systemic ketamine at 3 $\mathrm{mg} \cdot \mathrm{kg}^{-1}$ or intrathecal ketamine at any dose did not produce abnormal behaviour.

\section{Effects of intrathecal pretreatment of yohimbine and methysergide on the anti-hypersensitive action of sys- temic ketamine}

Intrathecal pretreatment with yohimbine or methysergide inhibited the anti-hypersensitivity effects of 30 $\mathrm{mg} \cdot \mathrm{kg}^{-1}$ of systemic ketamine $(P<0.05$, Dunn test, Figure 4). Pretreatment did not attenuate adverse effects such as abnormal behaviour associated with administration of $30 \mathrm{mg} \cdot \mathrm{kg}^{-1}$ of systemic ketamine. Intrathecal administration of each antagonist alone did not alter the withdrawal threshold (data not shown).

\section{Effects of systemic ketamine on c-fos expression}

c-fos protein immunoreactivity two hours after paw incision was detected mainly in the superficial laminae (laminae I/II) of the lumbar (L4-L5 segments) spinal cord ipsilateral to the side of the paw incision (Figure $5)$. There were no differences in the number of c-fos
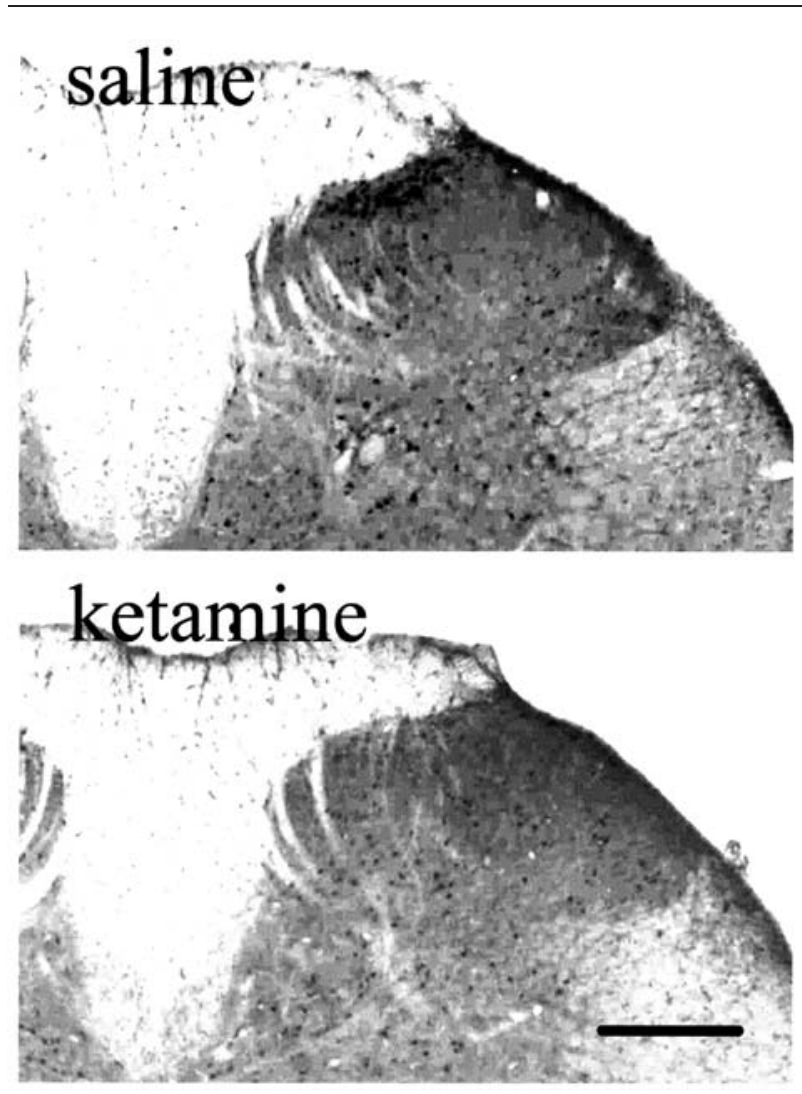

FIGURE 5 Photomicrographs of the ipsilateral dorsal horn of the lumbar spinal cord illustrating $\mathrm{c}$-fos expression in rats treated with saline or $30 \mathrm{mg} \cdot \mathrm{kg}^{-1}$ of ketamine immediately after surgery. Scale bar $=100 \mu \mathrm{m}$.

immunoreactive neurons between the ketamine-treated group and saline-treated group on the side of the spinal cord contralateral to the paw incision (data not shown). When $30 \mathrm{mg} \cdot \mathrm{kg}^{-1}$ of ketamine were administered immediately after paw incision, the number of c-fos immunoreactive neurons in laminae I-II was smaller than that in the saline-treated group $(P<0.05)$. The number of c-fos immunoreactive neurons in laminae III-IV and V-VI did not differ (Figures 5 and 6).

\section{Discussion}

In the present study, systemic but not intrathecal administration of ketamine produced anti-hypersensitivity effects at the early stage in a rat model of postoperative pain. Pretreatment with intrathecal yohimbine and methysergide reversed the effects of systemic ketamine in this model. These results suggest that ketamine activates monoaminergic descending inhibitory pathways at the supraspinal sites to produce 


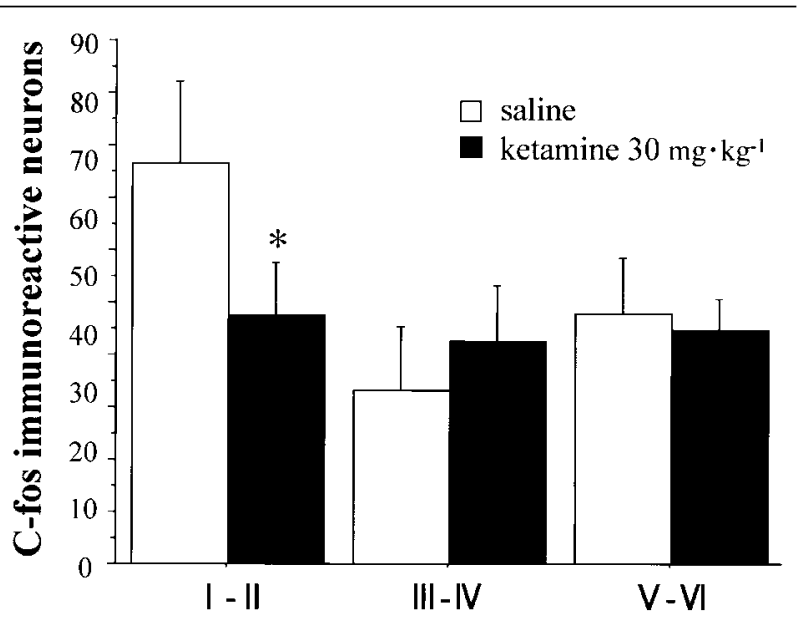

Laminae of L4-L5 spinal cord

FIGURE 6 Effect of systemic ketamine on the incision-evoked c-fos protein expression in the spinal cord. Each bar represents the mean $\pm \mathrm{SD}$, ketamine-treated group $(n=5)$, saline-treated group $(n=6) .{ }^{*} P<0.05$ vs saline-treated group.

anti-hypersensitivity effects in this model. In normal rats, ketamine produces antinociceptive effects through activation of the monoaminergic descending inhibitory pathways for acute thermal pain. ${ }^{22}$ The precise mechanisms underlying the interaction of ketamine with the monoaminergic descending inhibitory pathways remain unclear. Although the mechanism for the analgesic action of ketamine is similar to that of morphine, it may be different. ${ }^{19}$ Further, the periaqueductal grey region of the rat brain, which contains mu but no other opioid receptors, is not involved in ketamine-mediated analgesia. ${ }^{20}$ Kappa receptors are suggested to have a role in ketamine-mediated analgesia. Activation of a supraspinal site containing ketamine-sensitive opioid receptors on interneurons other than mu receptors might be the mechanism of analgesia of systemic administration of ketamine.

There were no anti-hypersensitivity effects of ketamine after intrathecal administration in the present study. A previous study also demonstrated that intrathecal ketamine does not have antinociceptive effects in acute thermal pain in rats. ${ }^{22}$ Other studies, however, demonstrate that intrathecal administration of ketamine reduces nerve injury-induced hyperalgesia $^{14,16}$ or inflammatory pain in rats. ${ }^{13,18}$ Although ketamine has NMDA receptor antagonistic activity, ${ }^{15}$ intrathecal administration of NMDA receptor antagonists does not modify the pain behaviours in this rat model of postoperative pain. ${ }^{6}$ Systemic ketamine produces antinociceptive effects via the monoaminergic descending inhibitory pathways in normal rats, but these pathways are not involved in the antihyperalgesic effects of systemic ketamine in rats with peripheral inflammation. ${ }^{22}$ Taken together, these observations indicate that the nature of incision-induced hypersensitivity in the postoperative pain model better approximates that of acute nociceptive pain than neuropathic pain or chemical inflammatory pain. Ketamine might also mediate antihyperalgesic effects via a peripheral mechanism. ${ }^{29,30}$ Peripheral mechanisms for the antihypersensitivity effects of systemic ketamine in the present study, however, cannot be excluded.

Systemic administration of ketamine produced adverse effects such as head weaving and circling behaviour. Although it persisted for 30 to $50 \mathrm{~min}$, these abnormal behaviours might not affect the withdrawal threshold, because rats returned to normal one hour after the administration, and righting and stepping reflexes are normally preserved. Intrathecal pretreatment with yohimbine and methysergide inhibited the anti-hypersensitivity effects of ketamine, but not the ketamine-induced abnormal behaviour. This finding suggests that the monoaminergic descending inhibitory pathways are not involved in the abnormal behaviour following ketamine administration.

In the present study, there was no difference between pre- and post-incisional administration of systemic ketamine on mechanical hypersensitivity after paw incision. Brennan et al. ${ }^{5}$ also reported that there was no difference in hyperalgesia induced by pre- and post-incision intrathecal morphine or bupivacaine treatment. Although several investigators examined preemptive analgesia with systemically administered ketamine in postoperative patients, most reported that systemic ketamine had no preemptive analgesic effect. ${ }^{31-33}$ These observations are consistent with our results. Immunocytochemical study revealed c-fos protein expression mainly in laminae I-II of the spinal cord two hours after incision of the plantar surface. The systemic administration of $30 \mathrm{mg} \cdot \mathrm{kg}^{-1}$ of ketamine immediately after surgery reduced c-fos protein expression in laminae I-II, but had no effect on the c-fos protein expression in laminae III-VI. These data strongly suggest that systemic administration of ketamine inhibits nociceptive input to the superficial laminae and produces an analgesic effect in the postoperative pain model. Huang and Simpson ${ }^{34}$ demonstrated that c-fos gene expression was induced in the dorsal horn by skin incision and that c-fos immunoreactivity was attenuated by systemic ketamine $\left(37.5 \mathrm{mg} \cdot \mathrm{kg}^{-1}\right)$. Our observation is consistent with this report. 
In summary, systemic but not intrathecal administration of ketamine produced anti-hypersensitivity effects in a rat model of postoperative pain. c-fos-positive neurons were decreased in the superficial laminae of the spinal cord in the ketamine-treated rats. The anti-hypersensitivity effects of systemic ketamine were inhibited by intrathecal pretreatment of either yohimbine or methysergide, indicating that activation of monoaminergic descending inhibitory pathways is, at least in part, involved in this action. Our results suggest that systemic ketamine inhibits early stage postoperative pain by a different mechanism than that of neuropathic pain or inflammatory pain.

\section{Acknowledgement}

The authors thank Drs. Tetsuo Fukuoka, Atsushi Tokunaga and Koichi Noguchi for their advice on methods of immunocytochemistory.

\section{References}

1 Stannard CF, Porter GE. Ketamine hydrochloride in the treatment of phantom limb pain. Pain 1993; 54: 227-30.

2 Eide PK, Jorum E, Stubhang A, Bremnes J, Breivik $H$. Relief of post-herpetic neuralgia with the N-methyl-Daspartic acid receptor antagonist ketamine: a doubleblind, cross-over comparison with morphine and placebo. Pain 1994; 58: 347-54.

3 Mathisen LC, Skjelbred P, Skoglund LA, Oye I. Effect of ketamine, an NMDA receptor inhibitor, in acute and chronic orofacial pain. Pain 1995; 61: 215-20.

4 Brennan TJ, Vandermeulen EP, Gebhart GF. Characterization of a rat model of incisional pain. Pain 1996; 64: 493-501.

5 Brennan TJ, Umali EF, Zahn PK. Comparison of preversus post-incision administration of intrathecal bupivacaine and intrathecal morphine in a rat model of postoperative pain. Anesthesiology 1997; 87: 1517-28.

6 Zahn PK, Brennan TJ. Lack of effect of intrathecally administered N-methyl-D-aspartate receptor antagonists in a rat model for postoperative pain. Anesthesiology 1998; 88: 143-56.

7 Schmid RL, Sandler AN, Katz J. Use and efficacy of low-dose ketamine in the management of acute postoperative pain: a review of current techniques and outcomes. Pain 1999; 82: 111-25.

8 Maurset A, Skoglund LA, Hustveit O, Oye I. Comparison of ketamine and pethidine in experimental and postoperative pain. Pain 1989; 36: 37-41.

9 McQuay HJ, Dickenson AH. Implications of nervous system plasticity for pain management (Editorial). Anaesthesia 1990; 45: 101-2.

10 Woolf CJ, Chong MS. Preemptive analgesia--treating postoperative pain by preventing the establishment of central sensitization. Anesth Analg 1993; 77: 362-79.

11 Dabl JB, Keblet $H$. The value of pre-emptive analgesia in the treatment of postoperative pain. Br J Anaesth 1993; 70: 434-9.

12 Hirota K, Lambert DG. Ketamine: its mechanism(s) of action and unusual clinical uses (Editorial). Br J Anaesth 1996; 77: 441-4.

13 Ren K, Williams GM, Hylden JL, Ruda MA, Dubner $R$. The intrathecal administration of excitatory amino acid receptor antagonists selectively attenuated carrageenan-induced behavioral hyperalgesia in rats. Eur J Pharmacol 1992; 219: 235-43.

14 ramamoto T, raksh TL. Spinal pharmacology of thermal hyperesthesia induced by constriction injury of sciatic nerve. Excitatory amino acid antagonists. Pain 1992; 49: 121-8.

15 Lodge D, Johnson KM. Noncompetitive excitatory amino acid receptor antagonists. Trends Pharmacol Sci 1990; 11: 81-6.

16 Mao J, Price DD, Hayes RL, Lu J, Mayer DJ, Frenk H. Intrathecal treatment with dextrorphan or ketamine potently reduces pain-related behaviors in a rat model of peripheral mononeuropathy. Brain Res 1993; 605: 164-8.

17 Qian J, Brown SD, Carlton SM. Systemic ketamine attenuates nociceptive behaviors in a rat model of peripheral neuropathy. Brain Res 1996; 715: 51-62.

18 Klimscha W, Horvath G, Szikszay M, Dobos I, Benedek $G$. Antinociceptive effect of the $\mathrm{S}(+)$-enantiomer of ketamine on carrageenan hyperalgesia after intrathecal administration in rats. Anesth Analg 1998; 86: 561-5.

19 Pekoe GM, Smith DJ. The involvement of opiate and monoaminergic neuronal systems in the analgesic effects of ketamine. Pain 1982; 12: 57-73.

20 Smith DJ, Perrotti JM, Mansell AL, Monroe PJ. Ketamine analgesia is not related to an opiate action in the periaqueductal gray region of the rat brain. Pain $1985 ; 21: 253-65$.

21 Nasstrom J, Karlsson U, Post C. Antinociceptive actions of different classes of excitatory amino acid receptor antagonists in mice. Eur J Pharmacol 1992; 212: 21-9.

22 Kawamata T, Omote K, Sonoda H, Kawamata M, Namiki A. Analgesic mechanisms of ketamine in the presence and absence of peripheral inflammation. Anesthesiology 2000; 93: 520-8.

23 Okuda T. Comparison of direct and indirect depressant actions of ketamine on dorsal horn cells in rabbits. Neuropharmacology 1986; 25: 433-40.

24 Tomemori N, Komatsu T, Shingu K, Urabe N, Seo N, Mori $K$. Activation of the supraspinal pain inhibition system by ketamine hydrochloride. Acta Anaesthesiol Scand $1981 ; 25$ : 355-9. 
25 Hunt SP, Pini A, Evan G. Induction of c-fos-like protein in spinal cord neurons following sensory stimulation (Letter). Nature 1987; 328: 632-4.

26 Harris JA. Using c-fos as a neural marker of pain. Brain Res Bull 1998; 45: 1-8.

27 raksh TL, Rudy TA. Chronic catheterization of the spinal subarachnoid space. Physiol Behav 1976; 17: 1031-6.

28 Molander C, Xu Q Grant G. The cytoarchitectonic organization of the spinal cord in the rat. I. The lower thoracic and lumbosacral cord. J Comp Neurol 1984; 230: 133-41.

29 Hustveit $O$, Maurset A, Oye I. Interaction of the chiral forms of ketamine with opioid, phencyclidine, $\sigma$ and muscarinic receptors. Pharmacol Toxicol 1995; 77: 355-9.

30 Oatway M, Reid A, Sawynok J. Peripheral antihyperalgesic and analgesic actions of ketamine and amitriptyline in a model of mild thermal injury in the rat. Anesth Analg 2003; 97: 168-73.

31 Holthusen H, Backhaus P, Boeminghaus F, Breulmann $M$, Lipfert $P$. Preemptive analgesia: no relevant advantage of preoperative compared with postoperative intravenous administration of morphine, ketamine, and clonidine in patients undergoing transperitoneal tumor nephrectomy. Reg Anesth Pain Med 2002; 27 : 249-53.

32 Dahl V, Ernoe PE, Steen T, Raeder JC, White PF. Does ketamine have preemptive effects in women undergoing abdominal hysterectomy procedures? Anesth Analg 2000; 90: 1419-22.

33 Adam F, Libier M, Oszustowicz T, Lefebvre D, Beal J, Meynadier J. Preoperative small-dose ketamine has no preemptive analgesic effect in patients undergoing total mastectomy. Anesth Analg 1999; 89: 444-7.

34 Huang $W$, Simpson RK Jr. Ketamine suppresses c-fos expression in dorsal horn neurons after acute constrictive sciatic nerve injury in the rat. Neurosci Lett 1999; 269: 165-8. 